\title{
The activity of selected gamma radionuclides in the Tatra National Park
}

\author{
Barbara Kubica $^{1 *}$, Marcin Stobiński ${ }^{1}$, Grzegorz Szaciłowski ${ }^{1}$, and Katarzyna Szarłowicz ${ }^{1}$ \\ ${ }^{1}$ AGH University of Science and Technology al. A. Mickiewicza 30-059 Cracow, Poland
}

\begin{abstract}
Cesium is naturally occurring active metal, represented by one stable isotope ${ }^{133} \mathrm{Cs}$, and number of artificial, unstable, isotopes. The most common artificial isotope of cesium is ${ }^{137} \mathrm{Cs}$, present in the environment of the Tatra Mountains due to nuclear weapon testing in late '50, and nuclear reactor accident in Chernobyl in 1986. However in recent years the growth in biofuels use for power generation can be the next source of ${ }^{137} \mathrm{Cs}$ emission. Burning wood cultivated on grounds contaminated by ${ }^{137} \mathrm{Cs}$ can introduce secondary emission of this isotope to the atmosphere.This paper presents the results of determination of gamma emitting radionuclides artificial ${ }^{137} \mathrm{Cs}$ and natural ${ }^{40} \mathrm{~K}$ in soil samples from the Tatra Mountains. Results show some differences in the vertical distribution of examined radionuclides. It was found that the change of activity of ${ }^{137} \mathrm{Cs}$ in the soil samples depends mostly on the soil density and on the concentration of organic material. The state of "zero" ${ }^{137} \mathrm{Cs}$ activity was developed in the form of maps.
\end{abstract}

\section{Introduction}

Radioactive substances are considered as one of the numerous types of pollution of the natural environment. However, various radionuclides are abundant in the environment from the Earth formation. The average content of radioactive isotopes in the Earth's crust is approx. $0.1 \%$ of which the most important are natural uranium and thorium. These elements are widespread in rocks, soil, and seas, lakes and rivers [1-5]. An example is also the potassium ${ }^{40} \mathrm{~K}$ isotope, the abundance of the natural potassium is equal to $0.0117 \%$, and the half-life $T_{1 / 2}=1.28 \cdot 10^{9}$ years [6]. In contrast, the origin of artificial radioactive elements is a major concern in respect to the natural environment with special emphasis put on the protected natural areas. The main source of their presence are: nuclear weapon tests conducted in the atmosphere, catastrophes of nuclear reactors (including the largest disaster in Europe - Chernobyl), controlled effluents from the nuclear fuel reprocessing plans [1-3, 7].

The contamination of large areas of Europe after the accident of the Chernobyl nuclear reactor in 1986 has become a challenge for many research centers. Especially important artificial radionuclide is ${ }^{137} \mathrm{Cs}$ for the reason of its rather long half-life (30,08 years) and

*Corresponding author: bkubica@agh.edu.pl 
large dispersion in the environment. Between the years $2000-2015$ there were made extensive studies of anthropogenic ${ }^{137} \mathrm{Cs}$ and natural ${ }^{40} \mathrm{~K}$ activity levels in soil [8-18].

This paper presents the research result concerned on the area of the Tatra Mountains. Mountain ecosystems, due to their enormous sensitivity to disruption of homeostasis, are ideal places to observe radiochemical contamination. The aim of this study was to determine the spatial distribution of gamma radionuclides: artificial ${ }^{137} \mathrm{Cs}$ and for comparison natural ${ }^{40} \mathrm{~K}$ in the soil samples taken from the whole region of the Tatra Mountains with special attention to the National Park areas.

\section{Materials and Methods}

\subsection{Study area}

The Tatra Mountains lie in the southern Poland and northern Slowakia, they consist of two mountain chains: The High Tatra Mountains and The Western Tatra Mountains. Despite the fact that they are the highest mountains in the Carpathian Mountains, their surface area is relatively small. Approximately their size corresponds to the average size of a single Alpine valley [24-27]. The entire Tatra Mountains area is legally protected by establishing of national parks. Due to its unique landscape and nature, the best preserved forest fragments of the Lower and Upper mountains, UNESCO acknowledged the Tatra Mountains as the World Biosphere Reserve.

\subsection{Field sampling}

The soil samples were taken from 245 sampling points (60 on the Polish and 185 on the Slovak side of the mountain range) situated in all main valleys (Fig. 1 and 2). The material was collected from June to October of 2000 - 2013. Soil samples were taken from the top layer using a cylindrical probe (diameter and height of $10 \mathrm{~cm}$ ). The soil core was divided into three equal parts namely: "a" $(0-3 \mathrm{~cm})$, "b" $(3-6 \mathrm{~cm})$ and "c" $(6-9 \mathrm{~cm})$. The part "a" relates to the top layer of the soil, and "c" was the deepest layer. The exact location (latitude and longitude coordinates and altitude) of the sampling points was determined using a satellite navigation system (GPS) and Garmin 76CS maps.

\subsection{Laboratory works}

The soil samples were dried at $105^{\circ} \mathrm{C}$, weighted (total mass), deprived of stones and large fragments of plants, and then grounded and sieved through the $2 \mathrm{~mm}$ sieve. The samples were placed into test vessels, weighed, and their bulk density was determined. The results were presented as activity $\left[\mathrm{Bq} \cdot \mathrm{kg}^{-1}\right]$ and as radioactive fallout $\left[\mathrm{Bq} \cdot \mathrm{m}^{-2}\right]$

Measurements of activity of ${ }^{137} \mathrm{Cs}$ and ${ }^{40} \mathrm{~K}$ were performed using semiconductor gamma-ray spectrometers equipped with coaxial, high purity germanium (HPGe) detectors of $15 \%$ relative efficiency. The efficiency calibration was performed by the use of the Reference Materials obtained from the International Atomic Energy Agency (IAEA-154 of certified activity of ${ }^{137} \mathrm{Cs}-3749 \mathrm{~Bq} \cdot \mathrm{kg}^{-1}$, and ${ }^{40} \mathrm{~K}-1575 \mathrm{~Bq} \cdot \mathrm{kg}^{-1}$, and IAEA-375, the certified activities were: ${ }^{137} \mathrm{Cs}-5280 \mathrm{~Bq} \cdot \mathrm{kg}^{-1}$, and $\left.{ }^{40} \mathrm{~K}-424 \mathrm{~Bq} \cdot \mathrm{kg}^{-1}\right)$. In order to maintain similar properties of the samples and the reference materials (such as matrix, density and sample geometry) further correction factors were included in the efficiency calibration. The most important correction factor was the self-absorption coefficient. This is correlated with the sample density, and refers to partial absorption of emitted gamma rays by the sample itself [17-20]. All samples were measured for 72 hours. 
Studies in the Tatra Mountains were performed during 15 years [8-18, 20-23]. Therefore in order to keep results comparable, the measured activities of ${ }^{137} \mathrm{Cs}$ are recalculated to the date of the $1^{\text {st }}$ September 2000.

\section{Results and discussion}

The cesium activity concentrations vary substantially, the highest content of this radionuclide was observed in the High Tatra Mountains and on the ridge connecting Grześ Mt and Wołowiec Mt in the Western Tatraa Mountains (Fig. 1 and 2). There is also a trend indicating the competitiveness of potassium and cesium sorption in soil. In places where the soil was depleted in potassium the activity of cesium was higher. Analyses of ${ }^{137} \mathrm{Cs}$ activity concentration in the Tatra soils show a great diversity of this radionuclide which ranged from $55.8 \mathrm{~Bq} \cdot \mathrm{kg}^{-1}\left(417.8 \mathrm{~Bq} \cdot \mathrm{m}^{-2}\right)$ for Tomanowa Pass (1685 m a.s.l.) to $5111 \mathrm{~Bq} \cdot \mathrm{kg}^{-1}$ $\left(8400 \mathrm{~Bq} \cdot \mathrm{m}^{-2}\right.$ ) for Pass Krzyżne (2112 $\mathrm{m}$ a.s.l.). After deposition cesium is readily bound by organic matter in the soil. Soil composition and properties in the Tatra Mountains, as in other mountainous systems, are closely related to climate, complexity of the vertical structure of vegetation, etc.

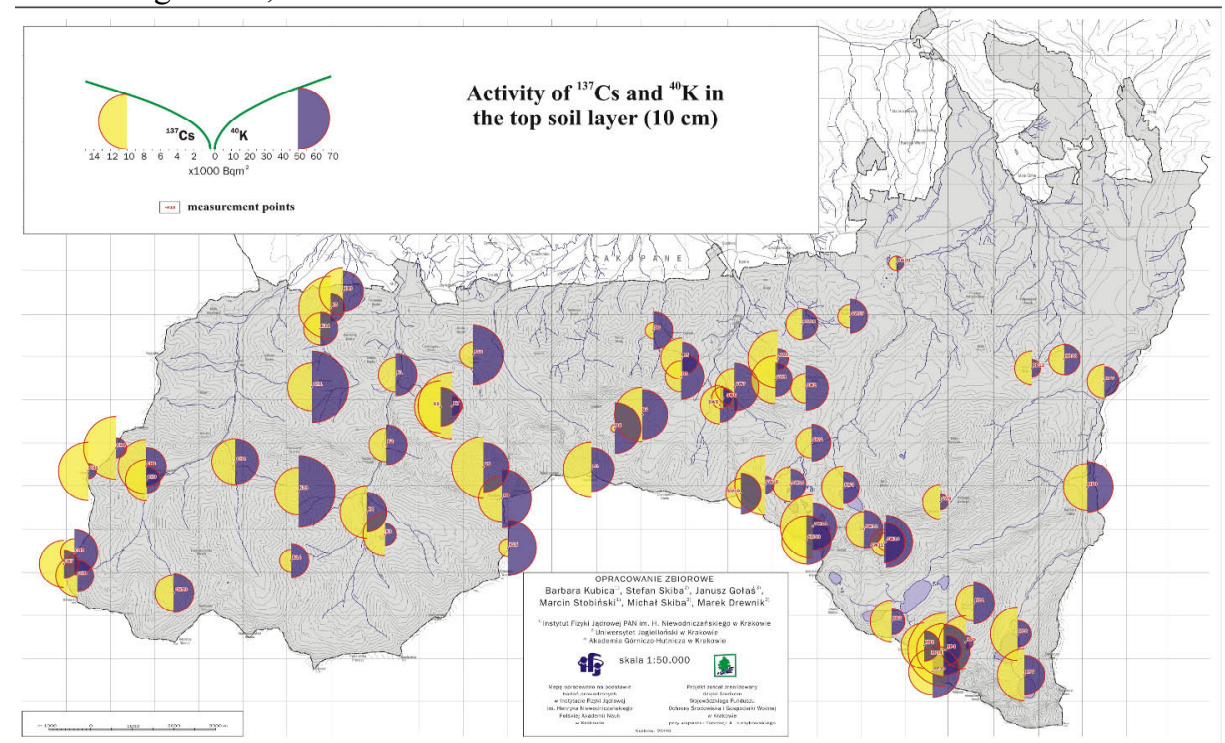

Fig. 1. The concentration of gamma radionuclides: artificial ${ }^{137} \mathrm{Cs}$ and natural ${ }^{40} \mathrm{~K}$ expressed in $\mathrm{Bq} \mathrm{m}^{-2}$ in soil samples taken from the Polish part of the Tatra Mountains.

With increasing altitude the humus level thickness increases which reveal a high sorption and a high ion exchange capacity. With increasing soil density which is concomitant with decrease of organic matter content in soil (what corresponds with decreased sampling point altitude) the cesium content is markedly decreased. Potassium follows the invers proportional tendency: with increasing density of the soil, natural potassium content also increases, because the mineral components of the soil, for example potassium feldspar, mica, clay minerals, either contain or adsorb it. 


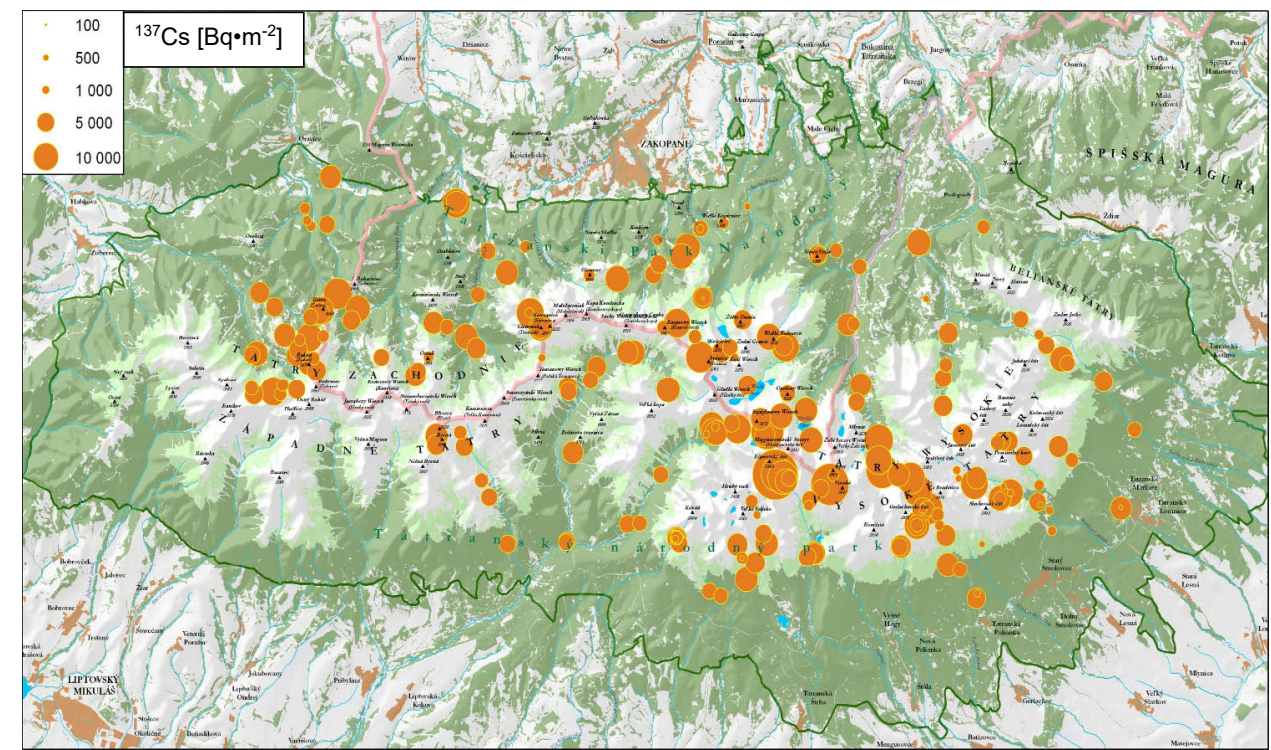

Fig. 2. The concentration of artificial gamma radionuclide ${ }^{137} \mathrm{Cs}$ expressed in $\mathrm{Bq} \cdot \mathrm{m}^{-2}$ in soil samples taken from the Tatra Mountains.

It can be seen from Fig. 2 that there is also a very large diversity of the ${ }^{137}$ Cs levels in the considered region. The highest ${ }^{137} \mathrm{Cs}$ activity was observed in the area of the High Tatra Mountains on both side of the Polish and Slovakia border.

After analysis of determined ${ }^{137} \mathrm{Cs}$ activities, eleven points were selected for annual monitoring in order to assess the change in the cesium activity and migration mechanism of this gamma radionuclide in the Tatra Mountains area. The measuring points were placed in at least two places in five main valleys in the Polish part of the Tatra Mountains. In the same measurement points activity of natural radioisotope ${ }^{40} \mathrm{~K}$ was verified. The changes in ${ }^{137} \mathrm{Cs}$ activity since 2000 to 2012 are presented in Fig. 3. In some locations the activity levels exceeds several times the average values reported for Poland, which equals $\mathbf{2 . 4 1}$ $\mathbf{k B q} \cdot \mathbf{m}^{-2}$ [28].

The activity concentrations of ${ }^{137} \mathrm{Cs}$ in many places of the Tatra Mountains showed decreasing tendency which may be explained both by radioactive decay and by migration processes occurring in the environment. Mainly, the process of cesium penetration into deeper soil layers with the organic forms and its sorption on aluminosilicates should be taken into consideration.

The activity of cesium in the year 2012 changed from $10.04 \mathrm{kBq} \cdot \mathrm{m}^{-2}$ for soil samples collected in the area of Staszicowe Stawki Lakes to $8.07 \mathrm{kBq} \cdot \mathrm{m}^{-2}$ for the samples situated in the vicinity of Morskie Oko Lake. This is almost 4 times higher comparing to the national average. 
Ordinarily, for the years 2000-2012 the decreasing tendency of cesium content in the surface layer of the soil was observed. This is obviously a result of ${ }^{137} \mathrm{Cs}$ movement downwards in the soil profile.

a

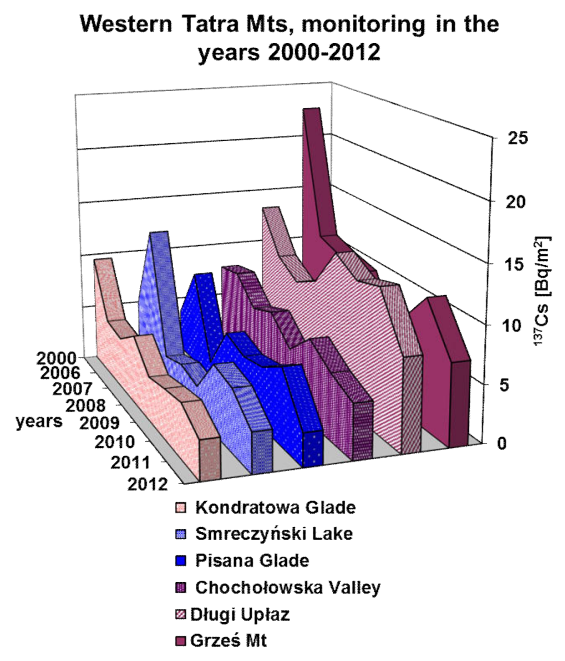

b

High Tatra Mts, monitoring in the years 2000-2012

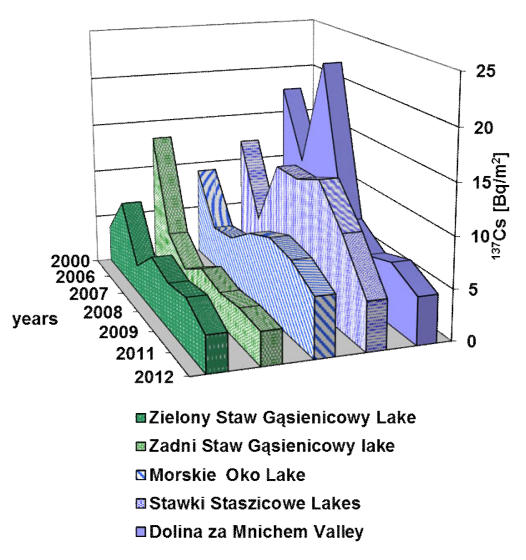

Fig. 3. The radioactivity of ${ }^{137} \mathrm{Cs}$ in the soil samples collected in the Western (a) and in the High Tatra Mountains (b) - monitoring in years 2006-2012.

The increase of ${ }^{137} \mathrm{Cs}$ content in the region of Morskie Oko Lake in the High Tatra Mountains (Fig. 3b) and on the ridge connecting Grzes Mt in the Western Tatra Mountains (Fig. 3a) can be explained by the higher rainfall rate. This may cause the ${ }^{137} \mathrm{Cs}$ introducing into environment from the upper parts of the atmosphere. It is supposed that in the higher parts of atmosphere the presence of cesium is an effect of Chernobyl accident.

Proving this thesis was taken up by the installation of probes containing a cesium selective composite sorbent with magnetic elements (hereinafter referred to as NiNCF) [29-30]. Supposing that the average rainfall in these regions amounted approximately $1700 \mathrm{~mm}$ per year, the calculated activity of cesium should be in the range from $5.61 \mathrm{mBq}$ to $37.4 \mathrm{mBq}$. The results (Table 1) point to higher activity of this gamma radionuclide (from $33.3 \mathrm{mBq}$ to $98.4 \mathrm{mBq}$ ). This fact can confirm the deduction that between $2007-2012{ }^{137} \mathrm{Cs}$ was introduced to the Tatra Mountains area along with atmospheric precipitation. 
Table 1. The amounts of ${ }^{137} \mathrm{Cs}$ collected on composite magnetic sorbent (NiNCF) in different places in the Polish part of the Tatra Mountains.

\begin{tabular}{|c|c|c|c|c|c|}
\hline $\begin{array}{c}\text { Sampling } \\
\text { points }\end{array}$ & $\begin{array}{c}2008 \\
{ }^{137} \mathrm{Cs} \\
{\left[\mathrm{mBq} \cdot \mathrm{kg}^{-1}\right]}\end{array}$ & $\begin{array}{c}2009 \\
{ }^{137} \mathrm{Cs} \\
{\left[\mathrm{mBq} \cdot \mathrm{kg}^{-1}\right]}\end{array}$ & $\begin{array}{c}2010 \\
{ }^{137} \mathrm{Cs} \\
{\left[\mathrm{mBq} \cdot \mathrm{kg}^{-1}\right]}\end{array}$ & $\begin{array}{c}2011 \\
{ }^{137} \mathrm{Cs} \\
{\left[\mathrm{mBq} \cdot \mathrm{kg}^{-1}\right]}\end{array}$ & $\begin{array}{c}2012 \\
{ }^{137} \mathrm{Cs} \\
{\left[\mathrm{mBq} \cdot \mathrm{kg}^{-1}\right]}\end{array}$ \\
\hline $\begin{array}{c}\text { Dhugi } \\
\text { Upłaz Mt } \\
1603 \mathrm{~m} \\
\text { a.s.l. }\end{array}$ & $65 \pm 31$ & $83 \pm 16$ & $46 \pm 27$ & $98 \pm 43$ & $78 \pm 49$ \\
\hline $\begin{array}{c}\text { Grześ Mt } \\
1639 \mathrm{~m} \\
\text { a.s.l. }\end{array}$ & $53 \pm 15$ & $61 \pm 15$ & $67 \pm 35$ & $56 \pm 31$ & $54 \pm 30$ \\
\hline $\begin{array}{c}\text { Staszicowe } \\
\text { Stawki } \\
\text { Lakes } \\
1893 \mathrm{~m} \\
\text { a.s.l. }\end{array}$ & $65 \pm 14$ & $85 \pm 19$ & $61 \pm 22$ & $86 \pm 37$ & $65 \pm 22$ \\
\hline
\end{tabular}

\section{Conclusions}

The following conclusions can be drawn:

- the activity of ${ }^{137} \mathrm{Cs}$ in the soil samples from the Tatra Mountains varies significantly from $55.8 \mathrm{~Bq} \cdot \mathrm{kg}^{-1}\left(417.8 \mathrm{~Bq} \cdot \mathrm{m}^{-2}\right)$ for Tomanowa Pass (1685 m a.s.l) to $5111 \mathrm{~Bq} \cdot \mathrm{kg}^{-1}$ $\left(8400 \mathrm{~Bq} \cdot \mathrm{m}^{-2}\right)$ for Krzyżne Pass $(2112 \mathrm{~m}$ a.s.l). In most locations, the values are not high, as well, they are lower than the average cesium concentrations established for Poland area;

- $\quad$ variety of the ${ }^{137} \mathrm{Cs}$ activity in the soil samples taken from the Tatra Mountains depend mostly on the soil volume density and on the content of organic matter;

- the activity of ${ }^{40} \mathrm{~K}$ increases with the depth of soil core while the ${ }^{137} \mathrm{Cs}$ level declines, in the soil surface layer (first $10 \mathrm{~cm}$ ) because of different origin of these two isotopes;

- annual research of cesium activity indicate a downward migration trend of this radionuclide.

This work was partially supported by the Grant of AGH University of Science and Technology No. 11.11.210.244. Some of the measurements were performed using the scientific equipment belonging to the laboratories of AGH-UST Energy Centre Cracow, Poland.

\section{References}

1. R. Broda, Acta Physica Polonica B 18, 935-951, (1987)

2. R. Broda, B. Kubica, Z. Szeglowski, K. Zuber, Radiochim. Acta 48, 89-96, (1989)

3. P. Jaracz, E. Piasecki, S. Mirowski, Z. Wilhelmi, J. Radioanal. Nucl. Chem. 141, 243$259,(1991)$

4. The team of the President of the National Atomic Energy Agency for the construction of a nuclear power plant in Żarnowiec: Report on the consequences of the disaster in Chernobyl (with attachments), Warsaw, PAA, (1991)

5. H. Bem, The radioactivity in the environment, Łódź, PAN, (2005)

6. A.Z. Hrynkiewicz, Man and ionizing radiation, (PWN, Warsaw, 2001)

7. W.P. Krasnov, Wyd. Wolyn, Zhytomyr, 112, (1998) 
8. B. Kubica, J.W. Mietelski, J. Gołaś, S. Skiba, E. Tomankiewicz, P. Gaca, M. Jasińska, M. Tuteja-Krysa, Polish J. Environ. Studies 11, 537-545 (2002)

9. B. Kubica, S. Skiba, J.W. Mietelski, J. Gołaś, M. Kubica, M. Stobiński, M. TutejaKrysa, E. Tomankiewicz, P. Gaca, Z. Krzan, Polish J. Environ. Studies 13, 153-159, (2004)

10. B. Kubica, M. Skiba, S. Skiba, J. Gołaś, M. Kubica, M. Stobiński, M. Tuteja- Krysa, J. Radioanal. Nucl. Chem. 266, 3-9, (2005)

11. P. Gaca, E. Tomankiewicz, J. W. Mietelski, S. Grabowska, B. Kubica, J. Radioanal. Nucl. Chem. 267, 443-448, (2006)

12. B. Kubica, W.M. Kwiatek, M. Stobiński, S. Skiba, M. Skiba, J. Gołaś, M. Kubica, M. Tuteja-Krysa, A. Wrona, R. Misiak, Polish J. Environ. Studies 16, 723-729, (2007)

13. J.W. Mietelski, B. Kubica, P.Gaca, E. Tomankiewicz, S. Błażej, M.Tuteja-Krysa, J. Radioanal. Nucl. Chem., 275, 523-533, (2008)

14. B. Kubica, S.Skiba, M. Drewnik, M. Stobiński, M. Kubica, J. Gołaś, R. Misiak, Nukleonika 55, 377-387, (2010)

15. M. Kłosowski, K. Kozak, J. Mazur, P. Olko, B. Kubica, P. Skawiński, A. CebulskaWasilewska, Rapid Diagnosis in Populations at Risk from Radiation and Chemicals 73, 351-361, (2010)

16. B. Kubica, M. Stobiński, S. Skiba, J. Gołaś, W. Reczyński, K. Szarłowicz, P. Fleischer, R. Misiak, W. Kwiatek, Science and Industry Research Spectroscopic in practice, a monograph, 533-542, (2011)

17. B. Kubica, An application of sparingly soluble hexacyanoferrates of divalent transition metal as sorbents (Habilitation thesis, Scientific Publishing PARAGRAPH, 2008)

18. M. Stobiński, An environmental risk assessment of radioactive cesium-137 and selected heavy metals accumulation in the Tatra National Park (doctoral thesis, 2011)

19. M. Mostajaboddavati, S. Hassanzadeh, H. Faghihian, M.R. Abdi, M. Kamali, J. Radioanal. Nucl. Chem. 268, 539-544, (2006)

20. P. Jodłowski, Nukleonika 51, 21-25, (2006)

21. J.P. Bolivar, M. Garcia-Leon, R. Garcia-Tenorio, Appl. Radiat. Isot. 48, 1125-1126, (1997)

22. L.S. Quindos, C. Sainz, I. Fuente, J. Nicolas, L. Quindos, J. Arteche, J. Radioanal. Nucl. Chem. 270, 339-343, (2006)

23. B. Kubica, M. Stobiński, R. Misiak, K. Szarłowicz, Science and industry spectroscopic methods in practice, new challenges and opportunities, 808-814, (2014)

24. Z. Mirek, Nature of the Tatra National Park, Tatra National Park, 595-617, (1996)

25. W. Siarzewski, Tatra National Park, (2005)

26. J. Nyka, Polish Tatras Mts - guide (Publishing Traverse 2011)

27. J. Nyka, Slovak Tatras Mts - guide (Publishing Traverse 2015)

28. M. Biernacka, K. Isajenko, P. Lipiński, M. Kuczbajska, Monitoring of the concentration of ${ }^{137} \mathrm{Cs}$ in soil- annual report for 2007, (Chief Inspectorate of Environmental Protection)

29. B. Kubica, Z. Szeglowski, M. Tuteja-Krysa, R. Fiałkowski, Patent No. 196361 issued 14.12.2007 "Composite magnetic ion exchanger"

30. B. Kubica, Z. Hubicki, M. Stobiński, K. Szarłowicz, M. Bartyzel, Patent No 217761 issued 14.08.2014 "The method of producing the composite sorbent based on NiFN" 